\title{
Michigan Michigan Michigan
}

\section{Vladimir Dedijer}

\section{The War Diaries of Vladimir Dedijer}

Volume 1: From April 6, 1941, to November 27, 1942

Volume 2: From November 28, 1942, to September 10, 1943

Volume 3: From September 11, 1943, to November 7, 1944

each volume $\$ 49.50$

set of three volumes $\$ 125.00$

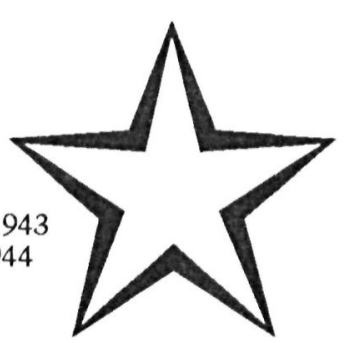

"The War Diaries of Dedijer are no scholar's compendium of dry dates and decisions. They are a blood-stained memento of heroic men and women fighting against impossible odds for the survival of their homeland . . . . They must be read in the uncompromising spirit in which they are written. Dedijer's artistic skills as a writer, his passion, and his emotion enrich his memoirs and make their reading an adventure in human experience."

-from the Foreword by Harrison Salisbury

\section{Nikolai Bukharin and Evgeny Preobrazhensky The ABC of Communism}

Preface and Introduction by Sidney Heitmann

The $A B C$ of Communism was to dedicated Bolsheviks of the twenties what the Communist Manifesto was to nineteenth-century Marxists. Written in 1919 in an atmosphere of crisis and dissension, Bukharin's book seethes with the ferment of revolution. Its aim is to explain the Communist party program to the people. It is both a theoretical exposition of communist philosophy and a practical guidebook.

As acknowledged party authority on Marxism after Lenin's death and as head of the Communist International from 1926 to 1929, Bukharin left an indelible mark on Soviet thought and development. He and Preobrazensky were executed in the bloody purges of the thirties when Stalin sought to obliterate the record of their achievements. With the advent of glasnost' Bukharin has been exonerated of the charges of treason. The $A B C$ of Communism was his most famous and widely read work. For anyone who wants to understand the past and future of Soviet policies, it is essential reading.

cloth $\$ 32.50$ / paper $\$ 12.95$

Michigan residents, include $4 \%$ sales tax.

\section{Mh The UnIVERsitr of Michigan Press MICHIGAN Dept. BI P.O. Box 1104 Ann Arbor, Michigan 48106}




\section{A SCHOOL FOR FOOLS SASHA SOKOLOV}

\section{TRANSLATED BY}

\section{CARL R. PROFFER}

"An enchanting, tragic and touching book. Sokolov's prose is unlike anything else in Russian literature." - Vladimir Nabokov

"It will undoubtedly come to be recognized as one of the great classics of Russian literature."

-Newsweek

"One of the most original and talented works to emerge from the Soviet Union in many years." - Times Literary Supplement

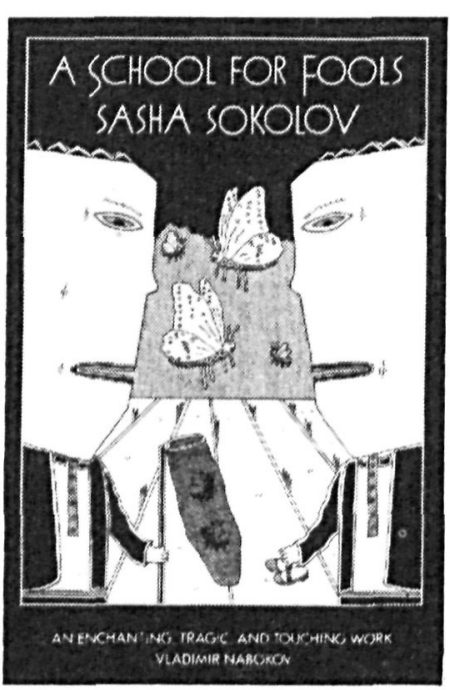

ISBN 0-941423-07-7 228 pages $/ \$ 9.95$

Sokolov's first novel is set at a school for "disturbed" children outside Moscow. Introduction by D. Barton Johnson, Professor of Russian at the University of California at Santa Barbara.

To order, call Consortium Book Sales, (612) 221-9035. For an exam copy, send a check or money order for $\$ 6.50$ to:

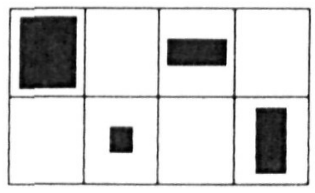

\section{Four Walls Eight Windows}

PO Box 548 New York, N.Y. 10014 
new from
Indiana

Now in paperback!

\section{Bolshevik} Culture

Experiment and Order in the Russian Revolution

\section{Edited by}

\section{Abbott Gleason,}

\section{Peter Kenez, and Richard Stites}

"By combining elements of social history, political theory and cultural analysis, [this volumel offers an innovative look at the ordered experiment of the early Soviet years." - The Russian Review

a finely textured, multidisciplinary look at a very complex period in Russian and Soviet cultural history. ... a fresh approach to the subject.

- American Historical Review

Studies of the Kennan Institute for

Advanced Russian Studies

cloth $\$ 35.00$ paper $\$ 14.95$

Now in paperback!

The Jews of Warsow. 1939-1943

Ghetto,

Underground,

Revolt

By Yisrael Gutman

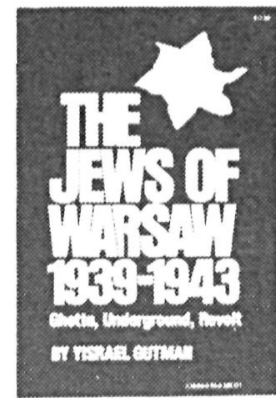

"The best recent book on the Warsaw ghetto is Yisrael

Gutman's The Jews of Warsaw, 1939-1943.

-Commentary

admirable and convincing."

- American Historical Review

an enduring monument."

- Times Literary Supplement

cloth $\$ \mathbf{\$ 0 . 0 0}$

paper $\$ 17.50$
Balancing

Acts

Contemporary

Stories by

Russian

Women

Edited by

Helena Goscilo

"A fine collection,

which expresses

poignantly the inner

lives and arduous

social problems of

Soviet women."

-Francine du Plessix Gray

Rich in revelations and eloquent detail, these 19 stories offer a composite selfportrait of modern Russian womanhoodan unparalle!ed opportunity to hear Russia's women speak for and about themselves in their own voices. cloth $\$ 39.95$ paper $\$ \mathbf{1 7 . 5 0}$

\section{Soviet Youth Culture}

\section{Edited by Jim Riordan}

Fascinating glimpses into the lives and attitudes of young Soviet men and women and a revealing look at little-known aspects of Soviet popular culture: the rock community. young artists and youth organizations, delinquents and deviants, the special problems of young people in the countryside and of returning Afghan veterans, and the political socialization of schoolchildren.

cloth $\$ 29.95$ paper $\$ 9.95$

\section{Russian Tenchers} and Peasant

\section{Revolution}

The Politics of

Education in 1905

By Scott J. Seregny

"As the first study in any language of the crucial social 'link' in rural Russia between broader society (obshchestvo) and the people (narod). Seregny's book will be read with great interest by all students of the late imperial period, Soviet and Western." - William G. Rosenberg Indiana-Michigan Series in Russian and East European Studies

cloth $\$ 27.50$

At bookstores, or direct from 


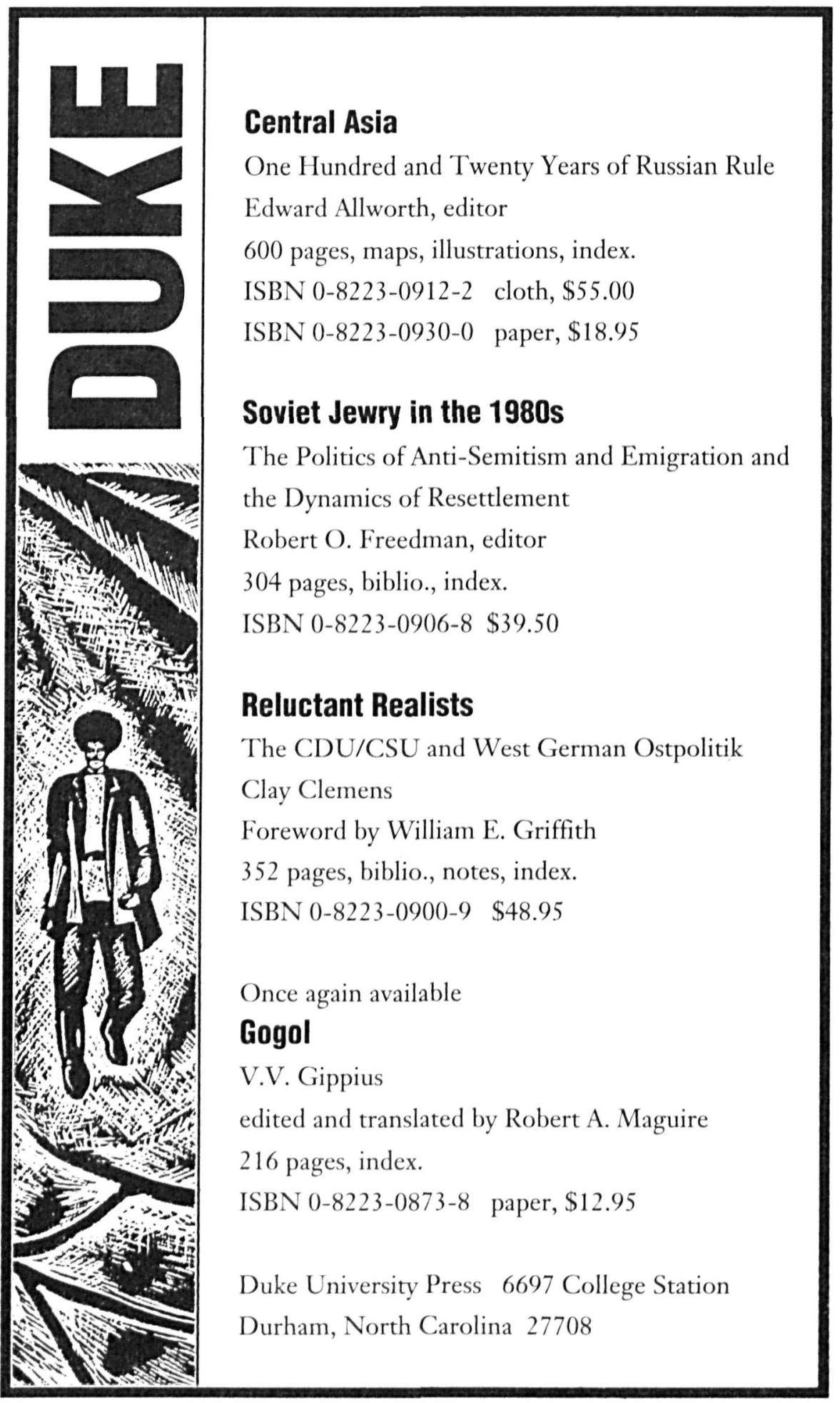




\section{East-West Forum Publications}

Politics, Society, and Nationality Inside Gorbachev's Russia

Seweryn Bialer, ed.

"These essays by prominent experts provide new information and insights on current trends in the Soviet Union, be they on elite politics or popular attitudes. A valuable and timely collection!"

-Alexander Dallin,

Stanford University

Jan. $1989 \cdot 255$ pp. $\bullet \$ 28.50$ (hc) •

$\$ 13.95(\mathrm{pb})$

\section{Central and Eastern Europe}

The Opening Curtain?

William E. Griffith, ed.

"This book makes a major contribution to the analysis of political and economic developments in this very important part of the world."

-John C. Whitehead,

former Deputy Secretary of State Apr. $1989 \cdot$ ca. 438 pp. $\bullet \$ 35(h c) \cdot 16.95$ (pb)

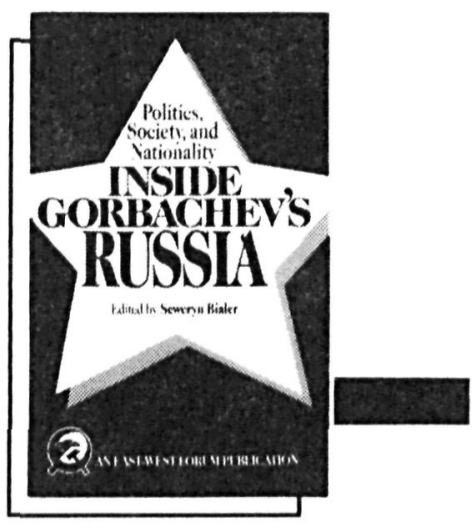

Gorbachev's Russia and American Foreign Policy

Seweryn Bialer and

Michael Mandelbaum, eds.

May 1988 - 510 pp. • \$36 (hc) •

$\$ 15.95(\mathrm{pb})$

\section{State and Society in the Soviet Union \\ Gail W. Lapidus}

Explores the changing character of statesociety relations. Original and previously published essays - which have been revised and updated-examine the long-term economic, social, and ideological trends that have been eroding key features of the state system. Nov. 1989 - ca. 256 pp. - \$35 (hc) • $\$ 16.50(\mathrm{pb})$

\section{Soviet/East European Survey, 1987-1988}

Selected Research and Analysis from Radio Free Europe/Radio Liberty

Vojtech Mastny, ed.

"This is a volume that all of us, East Europeanists and Sovietologists, should have at our fingertips."

-Daniel Chirot,editor,

East European Politics and Societies Dec. $1988 \cdot 413$ pp. • \$27.95 (sc)

\section{Westview Press}

5500 Central Ave. - Boulder, CO 80301 - (303) 444-3541 FAX (303) 449-3356 


\section{Studies}

Past and Present

\section{Gorbachev's Struggle for Economic Reform}

By ANDERS ÅSLUND.

Aslund, who served as an economic analyst in Moscow from 1984 to 1987 , here discusses how the present Soviet reform developed, the political and economic factors that have shaped its course, and its chances for success.

Studies in Soviet History and Society. \$12.95 paper, $\$ 38.50$ cloth

\section{Roads and Rivals}

The Political Uses of Access in the Borderlands of Asia

By MAHNAZ Z. ISPAHANI. In this account of the controversies and conflicts over Asian land routes, Ispahani looks at the history of access between Afghanistan, Pakistan, China, and the Soviet Union. "An outstanding, erudite work of scholarship."-Robert Litwak, Woodrow Wilson International Center for Scholars. $\$ 29.95$
Moscow and Greek Communism, 1944-1949

BY PETER J. STAVRAKIS

Stavrakis offers the first comprehensive analysis of

Soviet conduct in Greece during the most critical period of Greek history in this century - the last months of World War II and the years of the Greek Civil War. "An exceptionally fine and persuasive book."-Ivo Banac, Yale University. $\$ 28.95$

\section{Alien \\ Tongues}

Bilingual Russian Writers of the "First" Emigration

By ELIZABETH KLOSTY BEAUJOUR. Focusing on Vladimir Nabokov, Elsa Triolet, Vasily Yanovsky, and Zinaida Schakovskoy, Beaujour finds common patterns in the works and artistic development of major bilingual writers of the "first" emigration.

Studies of the Harriman Institute. \$29.95
Russian

Literary Politics and the Pushkin Celebration of 1880

By MARCUS C. LEVITT. In this richly detailed narrative history of the Pushkin Celebration and the developments that led up to it, Levitt explores the unique role of literature in nineteenth-century Russian intellectual life and puts Russian literary criticism, and Pushkin's posthumous reputation, into fresh perspective. Studies of the Harriman Institute. $\$ 27.50$

\section{Transition to Technocracy}

The Structural

Origins of the Soviet Administrative State By DON K. ROWNEY.

"Rowney's stimulating discussion of the influence of the Soviet administrative system on the rise of Stalinism adds to the timeliness and interest of this thoughtful investigation."-R. W. Davies, The University of Birmingham. Studies in Soviet History and Society. \$31.95

\section{O R N E L L Cornell University Press • 124 Roberts Place • Ithaca, NY 14850}




\section{U K R A I N E}

\section{A H I S T O R Y}

\section{Orest Subtelny}

In the first comprehensive single-volume history of Ukraine to be published in English in fifty years, Subtelny explores social, economic, cultural, and political developments through the five main periods of Ukrainian history. $\$ 49.95$

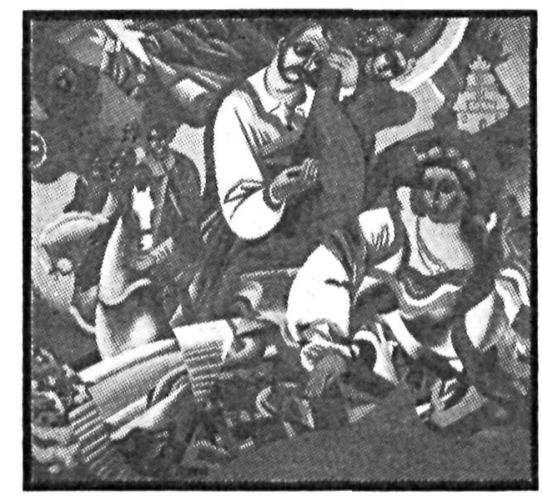

Now available again

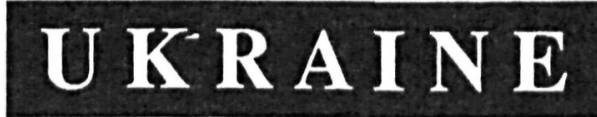

A CONCISE EN C Y CLOPEDIA

\section{Volodymyr Kubijovyc, Editor-in-Chief}

'This is perhaps the finest, most exacting reference book about the Ukraine and Ukrainians available anywhere in the English language.' Walter Poronovich, Montreal Star

'A vast body of authoritative reference material in English on Ukraine and its people, comprehensively designed and skilfully arranged for easy accessibility.' Ernest J. Simmons.

2-volume set $\$ 190$

\section{UNIVERSITY OF TORONTO PRESS} 340 NAGEL DRIVE, CHEEKTOWAGA, NY 14225 


\section{New from M. E. Sharpe}

\section{Soviet Society Today}

\section{Michael Rywkin}

In this engaging and very accessible introduction to contemporary Soviet society, Michael Rywkin takes the reader on a far-ranging guided tour of Soviet life-in the city and in the countryside, in the capitals and in the remote regions, among young and old, the elite and the disadvantaged. We trace the melding of traditional cultures with official ideology and examine the core institutions of the "system"-federalism, state management of the economy, one-party rule, bureaucracy, and secret police.

240 pages; bibliography; index; tables Cloth $\$ 35.00$ Paper $\$ 12.50$

\section{Russian Folk Belief}

\section{Linda J. Ivanits \\ Illustrated by Sophie Schiller}

A comprehensive survey of the Great Russian "lower mythology"- that is, folk beliefs about spirits and about human beings thought to have supernatural powers-this books offers a fascinating glimpse into the admixture of pagan and Christian elements that made up the Russian peasant's world view. These traditional beliefs have left their traces, not only in persisting superstitions and customs, but also in the works of Pushkin, Gogol, Dostoevsky, and innumerable other writers, as well as in the musical and figurative arts.

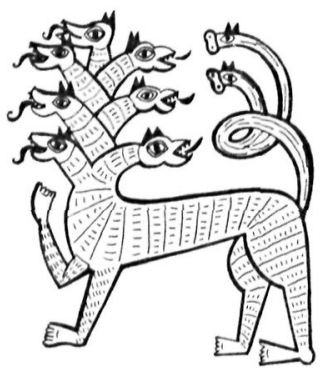
272 pages; illustrations; bibliography; index Cloth $\$ 35.00$

\section{A Voice of Reform}

\section{Essays by Tatiana I. Zaslavskaia}

\section{Murray Yanowitch, editor}

Collected here are eight important essays by Zaslavskaia which illustrate the considerable intellectual ferment in Soviet social science. Topics include the "human factor" in economic development, "restructuring"' and the problem of group interests, social justice, "openness" and democracy, as well as the startling document that has come to be known as "The Novosibirsk Report."

216 pages; illustrations; index Cloth $\$ 25.00$

\section{Quality of Life in the German Democratic Republic}

\section{Changes and Developments in a State Socialist Society Marilyn Rueschemeyer and Christiane Lemke, editors}

This volume presents the work of an international group of specialists on East German society, including social scientists from the U.S., the FRG, and the GDR. The intention of the collection is to give a more concrete and up-to-date understanding of everyday life in the GDR and its relationship to social structure, economy, and state policy.

257 pages; figures; photos; tables; bibliography Cloth $\$ 40.00$

๑M. E. Sharpe, Inc. 80 Business Park Drive, Armonk, NY 10504 


\section{NEW TITLES}

\section{In the Shade of the Giant}

Essays on Tolstoy.

HUGH McLEAN, Editor

All post-Tolstoy writers, whether Russian or foreign, have had to contend with his image. He and his books stand inescapably there: massive, majestic, seemingly impregnable. The essays in this volume add some further illumination to the world's quest for an understanding and appreciation of this great Russian master.

California Slavic Studies, 13

\section{The Gorbachev Phenomenon}

\section{A Historical Interpretation} MOSHE LEWIN

New in paperback - "Lewin's book is a grand essay of wide historical and sociological sweep.... Perhaps the study's most valuable contribution is the emphasis on the social changes Russia has undergone since 1917."

-New York Times Book Review $\$ 16.95$ cloth, \$9.95 paper

\section{Islam and the Russian Empire}

Reform and Revolution in Central Asia

HÉLENE CARRERE D'ENCAUSSE

With an Introduction by MAXIME RODINSON

Translated by QUINTIN HOARE

"A particularly valuable work. In my judgment, it contains the best account of nineteenth-century Muslim societies in Central Asia. It is, I think, indispensable to an understanding of the events that followed." -Ira Lapidus, co-editor of Islam, Politics and Social Movements Comparative Studies on Muslim Socieites, 8

At bookstores or call toll-free 1-800-822-6657. Visa \& MasterCard only.

$$
\text { University of California Press }
$$

Berkeley 94720 


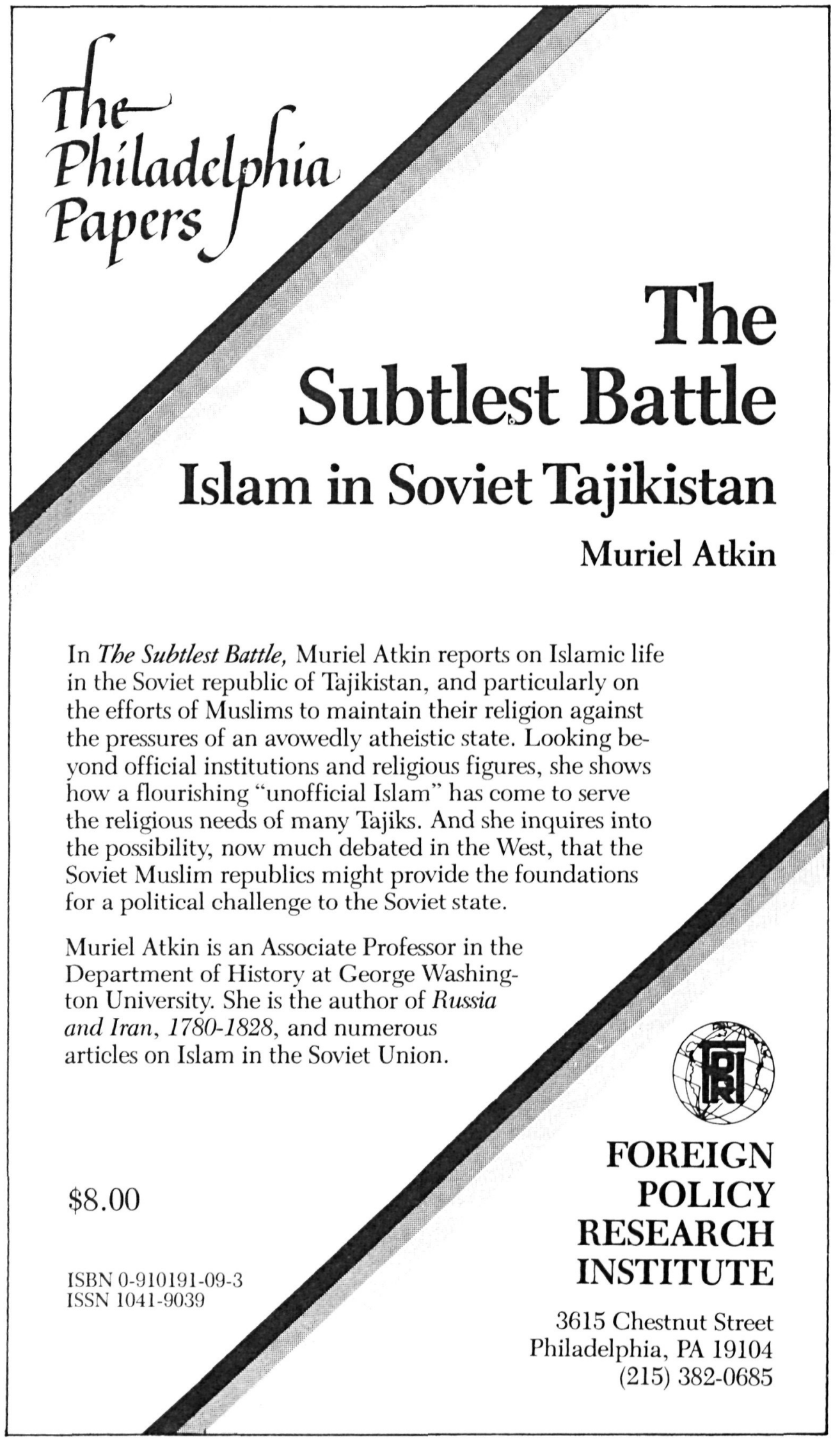


"Of considerable use to all who teach the earlier periods of Russian history."

-Slavic Review

THE NIKONIAN CHRONICLE

by SERGE A. ZENKOVSKY, Editor; translated by SERGE A. ZENKOVSKY and BETTY J. ZENKOVSKY

The Nikonian Chronicle is a monumental work dealing with Russian history from its earliest beginnings in the ninth century through the year 1520 . It is the last and most complete "official" Russian chronicle, compiled in the sixteenth century in the chancelleries of the metropolitans of Moscow and the rulers of Russia. This is the first English language edition.

About the Editor and Translators. Serge A. Zenkovsky, Professor Emeritus of Slavic Civilization and Literatures, Vanderbilt University, received his Ph.D. in History at Charles University in Prague. His co-translator, Betty Jean Zenkovsky, studied Russian language and literature at the University of Michigan, Indiana University, and Harvard University.

CONTENTS OF VOLUMES IN THE NIKONIAN CHRONICLE

Volume One: From the Beginning to the Year 1132. Description: Origin of the Slavs and the Russian state. Conversion of the first Russian princes to Christianity (around 870). Sviatoslav's campaign. Christianization of Russia by Vladimir (in 988). Iaroslav the Wise. Stories about the Kievan Cave Monastery. Vladimir Monomakh and his Writings.

Publ. 1984; ISBN 0-940670-00-3 (255 pages, lxxxi); $\$ 35.00$

Volume Two: From the Year 1132 - 1240. Description: Formation of the feudal principalities. Novgorod the Great. Struggle with the Polovtsy. Decline of Kiev. The rise of Suzdalia and Galicia. Vsevolod Great Nest. The Tatar-Mongol invasion.

Publ. 1984; ISBN 0-940670-01-1 (323 pages, xxxix); $\$ 35.00$

Volume Three: From the Year 1241 to the Year 1381. Description: Russia under the TatarMongols, 1240-1380. Alexander Nevsky defeats the Swedes, 1241. The rise of Moscow. Rivalry between Moscow and Tver'. Lithuanian expansion. Defeat of the Tatar-Mongols at Kulikovo, 1380. Publ. 1986; ISBN 0-940670-02-X (305 pages, xxxviii); $\$ 35.00$

Volume Four: From the Year 1382 to the Year 1425. Description: Invasions by Tokhtamysh and Tamerlane. Vasilii I and consolidation of the Principality of Moscow. Further Lithuanian expansion under Vitovt. The life of St. Sergius of Radonezh and the monastic movement.

Publ. 1988; ISBN 0-940670-03-8 (233 pages, xxxii) \$35.00

Volume Five: From the Year 1425 to the Year 1520. Description: Vasilii II and the struggle within the Muscovite dynasty. The blinding of Vasilii II. The Council of Florence. Unification of eastern Russia by Ivan III. End of the Tatar-Mongol Yoke, 1480. Disintegration of the Golden Horde. Vasilii III and wars against Lithuania.

Publ. 1989; ISBN 0-940670-04-6 (325 pages, xxxiii); $\$ 35.00$

To order directly from publisher, please write:

\section{THE DARWIN PRESS, INC. Box 2202, Princeton, NJ 08543 USA Tel: $609-737-1349$}




\section{HARVARD}

MISSIONARIES OF REVOLUTION

Soviet Advisors and

Nationalist China,

1920-1927

C. Martin Wilbur and

Julie Lien-ying How

During the 1920s the Soviet

Union made a determined effort to stimulate revolution in China. This was revolutionary Russia's first large-scale intervention in the affairs of a foreign country and the story of these missionaries of revolution constitutes an engrossing chapter on this little known enterprise.

"A true monument of historical scholarship that will be read and consulted by students of this period for a very long time to come." - Steven I. Levine, $\$ 65.00$ cloth Duke University

\section{KLAUS FUCHS,} ATOM SPY

Robert Chadwell Williams

"A wonderfully detailed picture of the shadowy world in which Fuchs operated."

- Peter Goodchild, Los Angeles Times $\$ 12.95$ paper
THE

INDUSTRIALIZATION OF SOVIET RUSSIA, 1968-1981

VOLUMEIV: THE SOVIET ECONOMY IN TURMOIL, R.W. Davies

In the spinal year of the first fiveyear plan, a vast investment program began the transformation of the Soviet Union from a peasant country into a great industrial power. This third volume of the unrivaled series The Industrialization of Soviet Russia reexamines the breakdown of the mixed economy.

Praise for the series:

"Eminently readable...the books can be profitably read by the non-specialist and specialist alike."

-Robert F. Miller, Soviet Studies $\$ 69.50$ cloth

\section{Harvard University Press \\ 79 Garden Street \\ Cambridge, MA 02138 \\ (617) $495-2480$}




\section{Perestroika in Perspective}

The Design and Dilemmas of Soviet Reform Padma Desai

Mikhail Gorbachev's perestroika is a historic effort at restructuring the troubled Soviet economy. How does perestroika relate to a more general environment of openness, of glasnost? Is the old order really giving way to a new one? To answer these questions and others, Padma Desai has distilled from Gorbachev's myriad decrees the outlines of his strategy for doing away with the Soviet Union's long-term economic malaise. Focusing on the key areas of industry, agriculture, services, and foreign trade, she discusses specific blueprints for change and evaluates the possibilities for their success.

Cloth: $\$ 14.95$ ISBN 0-691-04243-8

Not available in the British Commonwealth.

\section{Moscow's Third World Strategy} Alvin Z. Rubinstein

Gorbachev seems bent on avoiding a recurrence in the 1990s of the Soviet imperial covetousness that destroyed détente in the past. This book reminds us that he may not be ready to relinquish strategic advantage in the Third World. Alvin Z. Rubinstein provides an analytical framework for assessing the origins, evolution, impact, and aims of Moscow's actions in the Third World since World War II. He finds that Moscow sees the Third World as a vast arena for pursuing its global competition with the United States.

Cloth: $\$ 29.95$ ISBN 0-691-07790-8

\section{Esthetics as Nightmare}

\section{Russian Literary Theory, 1855-1870}

Charles A. Moser

As an epoch of "censorship terror" drew to a close with the end of the Crimean War, Russian intellectuals had begun expressing their desires for political, philosophical, and religious reform. Charles Moser re-creates the leading controversies over literature and art during a crucial period that saw the publication of such authors as Turgenev, Dostoevsky, and Tolstoy. He presents the doctrines of lesser known and major figures, both liberal and conservative, which influenced the development of Socialist Realism and Russian Formalism.

Cloth: $\$ 34.00$ ISBN 0-691-06763-5

AT YOUR BOOKSTORE OR

Princeton University Press

41 WILLIAM ST. • PRINCETON, NJ $08540 \bullet(609) 452-4900$

ORDERS 800-PRS-ISBN (777-4726) 


\section{Russia's Rulers Under the Old Regime}

Dominic Lieven

Drawing on previously untouched Soviet archival sources, Dominic Lieven here probes deeply into the lives and politics of the members of Tsar Nicholas II's State Council. His book tells us a great deal about the last ruling elite of Russia, about the role and personality of Nicholas, and about the coming of the Russian Revolution. 35 illus. $\$ 35.00$

\section{America Through Russian Eyes, I874-I926}

edited and translated by Olga Peters Hasty and Susanne Fusso

This engaging collection of travel accounts by Russian writers who visited America around the turn of the century offers fresh insights into both the American experience and the Russian mind.

"Very lively and exotic reading." -Richard Bridgman Illus. \$25.00

\section{The Materialist} Conception of History

Karl Kautsky

Abridged, annotated, and introduced by John H. Kautsky; translated by Raymond Meyer with John $\mathrm{H}$. Kautsky

An early disciple of Marx, Karl Kautsky was regarded as the leading turn-of-the-century interpreter of Marxism. Now his magnum opus-a Marxist explanation of human history and evolution - has been translated into English and abridged to make it accessible and useful to modern readers. $\$ 55.00$

\section{The Bolshevik Poster \\ Stephen White}

"A thoroughgoing study of the Soviet political poster at its apex." - Booklist

The first complete account of the great flood of political posters that emerged from the Bolshevik revolution. Stephen White looks at some of the key artists of the genre, placing them within a historical framework that illuminates the political and social conditions giving rise to the posters. $80 \mathrm{~b} / \mathrm{w}+90$ color illus. $\$ 39.95$

\section{Now available in paperback}

\section{Soviet Power and the Third World}

Rajan Menon

"A valuable contribution to the debate on Soviet intentions in the Third World." - Mark N. Katz, Russian Review

"In the spate of recent books on Soviet Third World policy, Rajan Menon's must rank as one of the best." - Peter Shearman, International Affairs $\$ 12.95$

\section{Mikhail Bakunin}

A Study in the Psychology and Politics of Utopianism

Aileen Kelly

"A brilliant and original intellectual biography of Bakunin." - James Joll, History

"A book as exciting intellectually as it is entertaining to read." - The Economist $\$ 14.95$

Yale University Press

Dept. ors

$92 \mathrm{~A}$ Yale Station

New Haven, CT o6s2o 
"Rethinking Bakhtin is singularly well-conceived and well organized . . it breaks Bakhtin out of dogma, his own or anybody else's.'

-Robert Jackson, Yale University

\section{RETHINKING BAKHTIN EXTENSIONS AND CHALLENGES}

\section{Edited by \\ GARY SAUL MORSON \\ CARYL EMERSON}

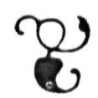

The essays in Rethinking Bakhtin extend the concepts of Mikhail Bakhtin in important new directions and challenge Bakhtin's own use of his most cherished ideas. Four sets of paired essays explore the theory of parody, the relation of de Man's poetics to Bakhtin's dialogics, Bakhtin's approach to Tolstoy and ideological literature, generally, and the dangers of dialogue, not only in practice but also as an ideal.

Contributors to this volume include Gary Saul Morson, Linda Hutcheon, Paul de Man, Mathew Roberts, Ann Shukman, Caryl Emerson, Aaron Fogel, and Michael André Bernstein. This collection also contains Emerson's translation of two previously untranslated Bakhtin texts-the prefaces to the complete works of Tolstoy.

Please send me Rethinking Bakhtin: Extensions and Challenges copies (hardcover) $\$ 39.95$

copies (paperback) $\$ 12.95$

[ ] Enclosed is my check for $\$$ payable to Northwestern University Press.

[ ] Please bill my credit card. I ] VISA [ ] MasterCard

Card No. Exp. Date

Signature

Name

Address

City State Zip

Telephone

Send to: Northwestern University Press / 625 Colfax Street / Evanston, Illinois 60201-2807 (312) $491-5313$ 


\title{
American Association for the Advancement of Slavic Studies
}

\author{
Membership Application Form \\ 1989
}

Please check category:

\begin{tabular}{|c|c|c|}
\hline \multirow[t]{5}{*}{ SALARY } & $\$ 50,000$ and over & $\$ 50[1]$ \\
\hline & $\$ 40,000$ to $\$ 49,999$ & $\$ 45$ [ ] \\
\hline & $\$ 30,000$ to $\$ 39,999$ & $\$ 40[$ ] \\
\hline & $\$ 20,000$ to $\$ 29,999$ & $\$ 35$ [ ] \\
\hline & $\$ 10,000$ to $\$ 19,999$ & $\$ 30[]$ \\
\hline \multicolumn{2}{|c|}{$\begin{array}{l}\text { STUDENT, EMERITUS, OR } \\
\text { SALARY UNDER } \$ 10,000\end{array}$} & $\$ 20$ 【 \\
\hline \multicolumn{2}{|c|}{$\begin{array}{l}\text { JOINT MEMBERSHIP FOR SPOUSES } \\
\text { (one subscription) higher category + }\end{array}$} & $\$ 10$ I \\
\hline \multicolumn{2}{|c|}{ AFFILIATE (AAASS Newsletter on $b$ ) } & $\$ 15$ I] \\
\hline
\end{tabular}

LIFE MEMBERSHIP

$\$ 1,000\lceil\mid$

BENEFACTOR

$\$ 500$ and above [ ]

FRIEND OF SLAVIC STUDIES $\$ 100$ and above [ ]

ADIITIONAL POSTAGE FOR NON-U.S.

MAILING ADDRESS (Surface mail) \$6 [ I

ADDITIONAL POSTAGE TO CANADA

CONTRIBUTION TO AAASS ENDOWMENT FUND

(Plcase indicate amount of contribution)

Payment in U.S. funds drawn on a U.S. bank only, plense.

All regular members receive the Slavic Review and the AAASS Newsletter; affiliate members recelve the AAASS Newsletter only (\$57.50 from the annual dues payment is applicd to a one year subseription to the AAASS Newsietler). For airmail delivery charges, check with the national office. For uninterrupted delivery and a full set of publications, membership dues must be recelved prior to MARCH 31. Note: AAASS membership is on a calendar year basis.

NON-MEMBER RATES FOR ANNUAL SUBSCRIPTIONS: Slavic Review, \$45; AAASS Newsletter, \$15

Slavic Review subscriptions sent to non-US addresses, add $\$ 6$ for surface mall postage (Canada: $\$ 5$ )

Please be sure to nil out BOTH SIDES of this form completely for the AAASS database on the field.

Last Name

First Middle

(Type or print clearly)

Office Address

(Institution \& Department)

City, State, Zip Office Phone(___

Home Address

City, State, Zip Home Phone(

Preferred Mailing Address: Office [ ] Home [ ]

Electronic Mailing Address: System Individual Address:

(e.g. Sovset; BITNEI)

FOR JOINT MEMBERSIIIP: Provide information below on second member for database; reverse side of this form should be photocopied and completed for second member.

Last Name First Middle

(Type or print clearly)

Office Address

(Institution \& Department)

City, State, Zip Office Phonel

Mail to: 128 Encina Commons, Stanford University, Stanford, CA 94305-6029; (415) 723-9668 
Please note: Disciplines, occupations, and degrees lacking equivalents among the catcgories employed cannot be entercd in the computerized database.

DEGREE YEAR RECEIVED INSTITUTION

Indicate main professional interest in each category. If more than one, rank by number $(1=$ highest $)$. List no more than three in any category.

\author{
POSITION \\ - Administrator \\ Business \\ - Editor/Publisher \\ - Government \\ - Instructor/Teacher \\ _ Librarian/Info. Specialist \\ - Military \\ - Full Professor \\ - Associate Professor \\ - Assistant Professor \\ - Adjunct Professor \\ - Professor Emeritus \\ - Researcher \\ - Retired \\ - Student \\ - Translator \\ - Other

COUNTRY/REGION
- Albania
- Balkans
- Baltic States
- Bulgaria
- Byzantine Empire
- Caucasus
- Central Asia
- Czechoslovakia
- Eastern Europe
- German Democratic Republic
- Greece
- Habsburg Empire
- Hungary
- Ottoman Empire
- Poland
- Romania
- Russia/USSR
- Ukraine
- Yugoslavia

*(Information to be used for statistical purposes only; it will not be published.)

\author{
PERIOD (if applicable) \\ pre-18th century \\ 18th \& 19th centuries \\ - 19th \& 20th centuries \\ - 20th century

\section{FIELD} \\ General \\ Anthropology/Folklife \\ - Arts \\ Communications \\ Demography \\ Economics \\ Education \\ Folklore \\ Geography \\ - History \\ Intl Relations/Foreign Policy \\ - Language \\ - Law \\ - Library/Information Sciences \\ - Linguistics \\ Literature \\ Military Affairs \\ Philosophy \\ Political Science \\ - Psychology/Psychiatry \\ Religion \\ - Science/Technology \\ - Sociology \\ _ Women's Studies \\ Other
}

\section{PERCENTAGE TIME IN FIELD*}

Are you engaged full-time in Russian/ Soviet/East European Studies?

Yes [ ] No [ ]

If not, indicate percent time spent in field:

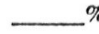

Of the time you do spend in the field, indicate percent devoted to: Russian/Soviet Studies:

East European Studies:
LANGUAGES (used or usable professionally) Write one of the following letters next to your rank order number to indicate level of competency (e.g. 1 B Albanian): $A=$ Fully Fluent

$\mathrm{B}=$ Adequate for most needs

$C=$ Marginally Usable

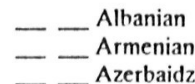

- Azerbaidzhani

- Belorussian

_ Bulgarian

- Croatian

- Czech

_ Estonian

- Finnish

_ Georgian

German

_ - Modern Greek

- Hungarian

- Kazakh

_ Kirghiz

- Latvian

_ Lithuanian

- Macedonian

_ Mongolian

_ Polish

- Romanian

_ Russian

- Serbian

- Serbo-Croatian

_ Old Church Slavonic

_ Slovak

- Slovenian

- Tadzhik

_ - Tatar

- Turkmen

- Uighur

- Ukrainian

- Uzbek

—_ Yiddish

- Other 


\section{IN FORTHCOMING ISSUES}

Michael S. Fox, "Ante Ciliga, Trotskii and 'State Capitalism': Theory, Tactics, and the Oppositionist Split, 1935-1939"

Susan Amert, "Akhmatova's 'Song of the Motherland': Rereading the Opening Texts of Rekviem"

Vladimir Shlapentokh, "Alexander II and Mikhail Gorbachev: Two Reformers in Historical Perspective"

Carol Any, "Boris Eikhenbaum in Opoiaz: Testing the Limits of the Work-Centered Poetics"

Beatrice Farnsworth, "The Soldatka: Folklore and Court Record"

\section{TO THOSE WISHING TO SUBMIT MANUSCRIPTS}

Manuscripts for consideration should be submitted in four double-spaced typed copies. (If manuscripts are computer generated, they should be letter quality or near letter quality.) Notes and block quotations should also be double-spaced; Notes should be placed at the end of the article and not at the bottoms of pages. Manuscripts are sent to readers anonymously and should be prepared accordingly. Library of Congress transliteration and the Chicago Manual of Style are to be followed. In general articles should not exceed twenty-five pages $81 / 2 \times 11$ in dimension-including endnotes. Manuscripts will not be returned unless postage is included; please do not send checks.

The policy of the Slavic Review is not to consider materials that have been published or that are being considered for publication elsewhere.

Publication of articles in the Slavic Review is ordinarily limited to those submitted by members of AAASS. Nonmembers wishing to submit manuscripts are asked to request a membership application. 


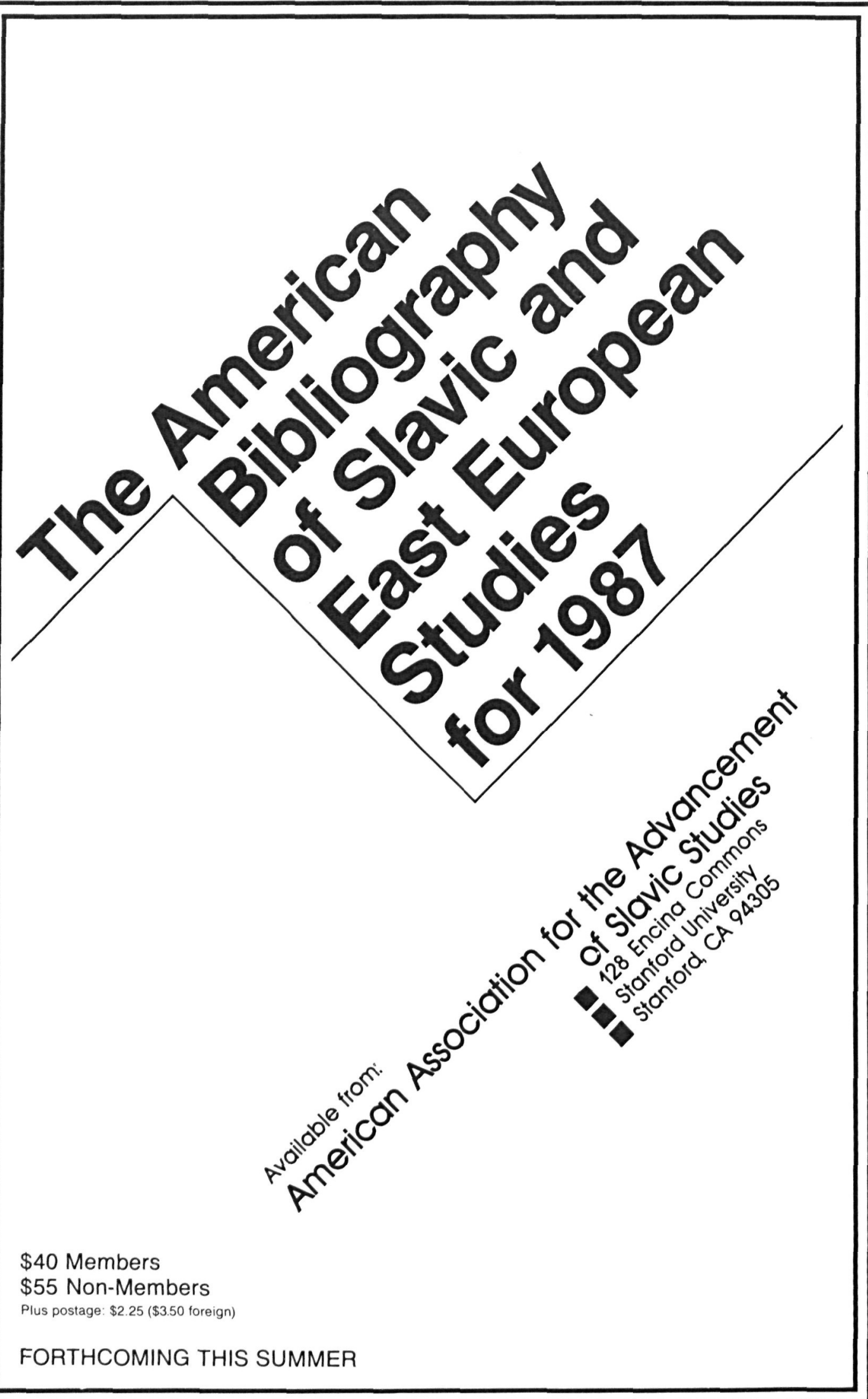

